\title{
Comparative Study of Soy Paneer Prepared from Soymilk, Blends of Soymilk and Skimmed Milk
}

\author{
Jeelani Raja*, Hillal A Punoo and Farooq A Masoodi
}

Department of Food Science and Technology, University of Kashmir, Srinagar-190006, India

\begin{abstract}
The present investigation was made with an attempt to develop processed paneer by partial addition of different levels of skimmed milk and soymilk. Soy paneer sample A (control) was prepared with $100 \%$ soymilk using citric acid at a concentration of $1.5 \%$ as coagulant. Sample B and Sample C were prepared with soymilk and skimmed milk in the ratio of 50:50 and 75:25 respectively with the addition of citric acid (1.5\%) as coagulant. The samples were first processed at $80^{\circ} \mathrm{C}$ for 20 minutes and later at $30^{\circ} \mathrm{C}$ for 15 minutes. The control and different treatments were analyzed for physico-chemical analysis (acidity, TSS, specific gravity, ash, moisture, fat and protein) and organoleptic characteristics like (colour, flavor, taste, texture and overall acceptability). It was found that sample $\mathrm{C}$ has highest protein, fat and ash content. The soy paneer samples were subjected to sensory analysis by nine point hedonic scale. The sample containing 75:25 levels of soymilk and skimmed milk was liked most by the sensory panelists in comparison to other samples.
\end{abstract}

Keywords: Soymilk; Skimmed milk; Soy paneer; Organoleptic

\section{Introduction}

Soybean (Glycine max) is a leguminous plant. Majority of nonvegetarian people do not consume animal products on a daily basis in quantities sufficient to provide the recommended amount of protein. Soybeans are a rich source of good quality protein. Besides nutritional benefits soybeans provide several therapeutic benefits too. Soybean is one of the very few plants that provide high quality protein. Soybeans contain all the major macronutrients required for good nutrition, as well as fiber, vitamins, minerals. Soybean protein provides all the essential amino acids in the amounts needed for human health. Soybean meal is the supplemental protein source most widely used in animal feeds. Soybean meal is an excellent source of protein, because nearly $480 \mathrm{~g} / \mathrm{kg}$ of the Dry Matter (DM) is protein and the protein quality is high [1]. Soybeans have almost $40 \%$ protein, making soybeans higher in protein than any other legumes and many animal products. The quality of soy protein is virtually equivalent in quality to that of milk and egg protein. The composition of soybean seed not only affects the soymilk and soy paneer quality but also its yield [2]. Unlike many other good sources of protein, soybean not only has higher percentage of oil but also quality fatty acid profile. It has low saturated fat content with high amount of essential fatty acids. Soybean oil obtained from the soybean is also a good source of omega- 3 and 6 fatty acids similar to those found in fish oils and are cholesterol-free. Soybeans are an excellent source of dietary fiber with both soluble and insoluble fiber.

Soymilk is a creamy, milk-like product made by soaking and grinding soybeans in water. However the water absorption of soybeans in soaking is directly related to the changes in textural characteristics and grinding properties of soybeans for processing [3]. Soybean or soymilk has always been a rich source of protein which is inexpensive [4] and abundantly available. Soymilk is used in various food products such as tofu, fruit flavored puddings, calcium and protein rich soymilk. Soy milk (also called soymilk, soybean milk) and sometimes referred to as soy drink/beverage is a beverage made from soybeans. A stable emulsion of oil, water, and protein, it is produced by soaking dry soybeans and grinding them with water. Soy milk contains about the same proportion of protein as cow's milk: around 3.5\%; also $2 \%$ fat, $2.9 \%$ carbohydrate, and $0.5 \%$ ash besides being rich in protein, vitamins and minerals. Soy milk is an intermediate product in the manufacture of soy paneer. It is often used in confections, meat fillers, beverages, and as part of infant formulas for children allergic to dairy milk [5]. Soymilk is very economical, lactose free, highly digestible and nutritious alternative of dairy and meat centered diet. It is cholesterol free product, has a very low fat content and is rich in polyunsaturated fatty acids of phospholipids. Generally soymilk contains around 7-8\% TSS in it. Adding 3-4\% sugar and about $0.05 \%$ salt brings it to a sugar, salt and total solid level approximately identical to toned ( $2 \%$ fat) cow's milk, i.e. about $12-13 \%$ TSS. It can be made into yogurt (curd) or tofu (paneer) or used directly in cooking. In addition to that blends of the soymilk with cow/buffalo milk have been successfully tried for the preparation of different varieties of soy paneer. Soymilk contains some anti-nutritional constituents also. Soymilk is good source of calcium and helps to avoid osteoporosis. Soluble fiber in soymilk controls blood sugar. It is good for pregnant women and lactating mothers. Soymilk reduces menopausal symptoms and bone deformities. Soya foods contain calcium, magnesium and phosphorus, which help to strengthen teeth and prevent nerve disorder. Soybean consumption on regular basis delays the ageing process.

Soy paneer is known for its extraordinary nutritional benefits, as well as its versatility. Soy paneer is a soft cheese-like food made by curdling soya milk with a coagulant. To improve the texture and increase the yield of tofu, researchers has been engaged to find better coagulation methods, concentration of coagulants and optimum temperature of coagulation. Researchers [6] studied the effect of two different coagulants calcium sulphate and modified nigari (Japanese

*Corresponding author: Jeelani Raja, Department of Food Science and Technology, University of Kashmir, Srinagar-190006, India, Tel: 9596011200; E mail: jeelaniraja743@rediffmail.com

Received September 28, 2013; Accepted February 27, 2014; Published March 19,2014

Citation: Raja J, Punoo HA, Masoodi FA (2014) Comparative Study of Soy Paneer Prepared from Soymilk, Blends of Soymilk and Skimmed Milk. J Food Process Technol 5: 301. doi:10.4172/2157-7110.1000301

Copyright: (C) 2014 Raja J, et al. This is an open-access article distributed unde the terms of the Creative Commons Attribution License, which permits unrestricted use, distribution, and reproduction in any medium, provided the original author and source are credited. 
name for magnesium chloride), three stirring speeds (137, 207 and $285 \mathrm{rpm})$, and six stirring times $(5,10,15,20,25$ and $30 \mathrm{sec})$ on yield and textural properties of soft tofu. They found that tofu made by the highest stirring speed $(285 \mathrm{rpm})$ had a lower yield, but higher brittleness force, hardness and elasticity than tofu made at $207 \mathrm{rpm}$. Other factors that affected yield of tofu were whole soybean (higher yield) versus soybean flakes [7], heating method where steam injected cooker system had higher yield as compared to steam jacketed kettle system [8]. Soy is easily digestible from of protein, and is the only complete protein food source in the plant Kingdom. Other health benefits of soy include calcium, iron, B vitamins and naturally occurring phyto-estrogens. The effect of soybean storage affects the textural properties of the soy paneer developed from it [9]. Soy paneer is usually packaged in water and should be refrigerated and kept in water until used. Soy paneer can be frozen for up to three months. It is dense and can be cubed and stir-fried, grilled, scrambled, pickled, smoked, baked, barbecued or served in soups. Different yogurt-like products were prepared from the combination of skim milk and soymilk [10]. The present study was selected to develop Soy paneer from soymilk and blend of soymilk and skimmed milk and to evaluate the sensory and physico-chemical properties of the product.

\section{Materials and Methods}

Soybean seeds of the variety "Pooja" were procured from the local market. The coagulant used in the experiment was citric acid.

\section{Preparation of soymilk}

Soy bean seeds were soaked in water $(1: 3 \mathrm{w} / \mathrm{v})$ for $14-16 \mathrm{hrs}$. The soaked water was decanted and the seeds were washed with fresh water. Hundred grams of soaked soybean seeds per litre of water was used for grinding i.e. 1:10 (w/v). The resulting suspension was filtered through a double layered muslin cloth. The muslin cloth was wrapped around the bean pulp, okara and squeezed till all the liquid was extracted. The filtrate obtained was boiled in water bath at $80^{\circ} \mathrm{C}$. The soymilk was then cooled and refrigerated for 3 days [11]. The flow chart for the preparation of soymilk is shown in the Figure 1.

\section{Preparation of soy paneer}

Soy paneer is one of the most popular soy-products and is prepared by coagulating soymilk. Soypaneer has been reported as low-calorie food and is rich source of iron, calcium, low in saturated fat and as a source of isoflavones which can mimic human estrogens and can have beneficial effects on human health [12]. Soy paneer was prepared in the laboratory at Department of Food Technology, University of Kashmir (India) using 1L of soymilk for each experimental trial. A solution of $1.5 \%$ citric acid was used to coagulate soymilk. Soymilk samples were heated to coagulation temperatures of $80^{\circ} \mathrm{C}$. The coagulant was added into soymilk slowly with gentle and continuous stirring. After complete coagulation, stirring was stopped and contents were left undisturbed at room temperature of $30^{\circ} \mathrm{C}$ for $15 \mathrm{~min}$. Whey was then removed by straining through a muslin cloth. The coagulum (soy paneer) obtained was pressed. It was removed and soaked in cold water for $30 \mathrm{~min}$ [11]. Then it was taken out and the free water on the surface was removed by wrapping paneer blocks on a clean muslin cloth. The method adopted in the preparation of soy paneer is shown in Figure 2. The soy paneer yield was expressed as kg soy paneer per kg of raw dry beans [13]. Tofumaking procedures generally include soaking and grinding of soybeans in water, filtering, boiling and coagulation of soymilk, and molding and pressing of bean curds. Tofu is usually sold in the form of a wet cake with a creamy white color, smooth texture, and bland taste [14].

\section{Physico chemical analysis}

Determination of acidity: Acidity in soymilk was determined by using the procedure described in Handbook of analysis and quality control for fruit and vegetable products (second edition) by Rangana, [15]. However for soy paneer, dilute it with water before titration in the ratio of $1: 1$.

Determination of total soluble solids (TSS): Total soluble solids (TSS) of soymilk as well as soy paneer were determined by using a hand refractometer or Abbey's refractometer and readings were expressed as Brix.

Determination of specific gravity: Specific gravity of soymilk was calculated by using Lactometer. The soymilk sample was filled in a 100 $\mathrm{ml}$ cylinder. Lactometer was introduced into the cylinder Readings were taken at which the soymilk touches the stem of the lactometer. Specific gravity was calculated using the formula as:

$$
\text { Specific Gravity }=\frac{C L R}{1000}+1
$$

Where,

\section{CLR is correct Lactometer reading.}

Determination of ash: Ash percentages of soymilk and soy paneer samples were determined by using the procedure as described in Handbook of analysis and quality control for fruit and vegetable products (second edition) by Rangana [15].

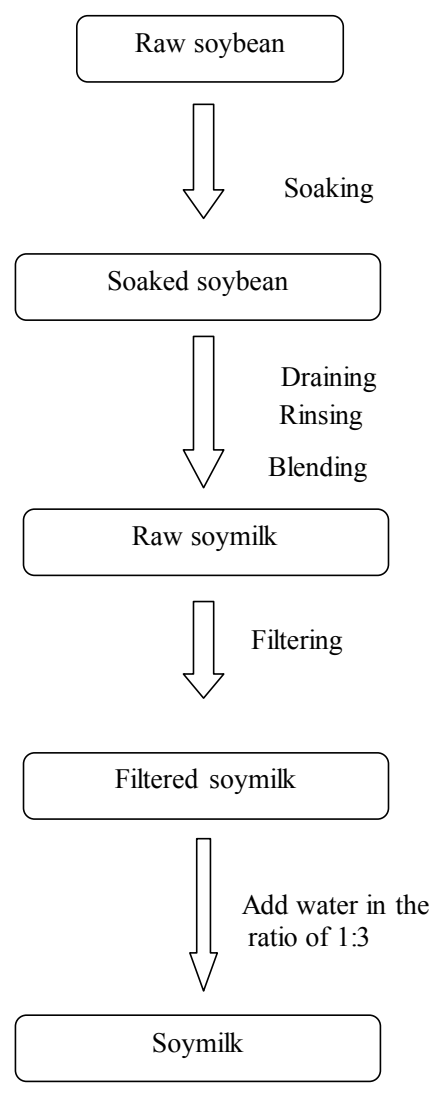

Figure 1: Flow chart for the Preparation of soymilk. 


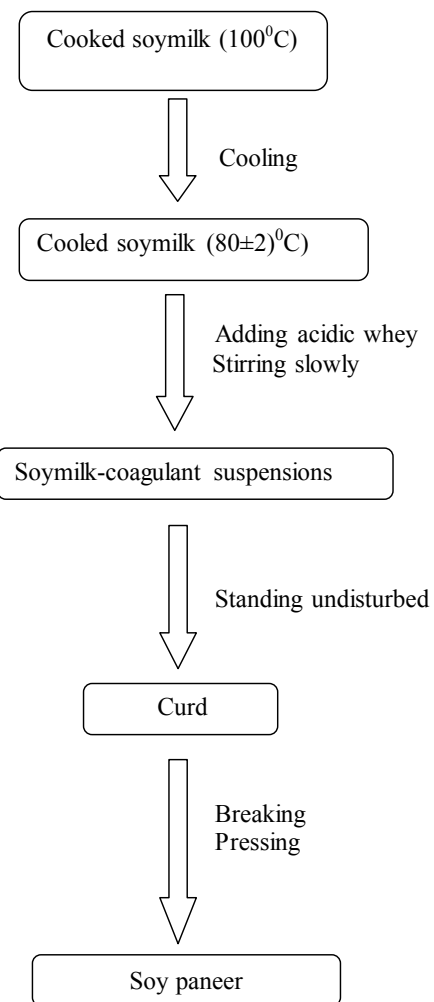

Figure 2: Flow Chart for the preparation of Soy paneer.

Determination of moisture: The moisture content was determined as per the procedure given in manual in dairy chemistry, I.C.A.R.

Determination of fat: Fat percentage was determined by Gerber method as per adopting the procedure as laid down in manual in dairy chemistry I.C.A.R.

Determination of protein: The protein content was determined by kjeldahl method described in AOAC [16].

Sensory evaluation of soy paneer samples: Sensory evaluation of the soy paneer prepared from different samples was done by using nine-point hedonic [17].

Statistical analysis: All treatments were evaluated in triplicate. Data were analyzed using the basic statistics and mean, median and range were calculated and differences among treatment means were evaluated by ANOVA (analysis of variance). Statistical significance was established at $\mathrm{p}<0.05$. Correlation coefficients were calculated using Pearson's technique for all parameters involved [18].

\section{Results and Discussion}

The results obtained for soymilk and soy paneer samples are discussed as:

\section{Fat percentage}

The average value of fat in soymilk sample A was found to be 1.80 $\%$. The sample B \& sample $\mathrm{C}$ of soymilk have average fat percentage of 1.9 and 2.55 respectively as shown in Table 1.

The average fat percentage in soy paneer sample A was $1.85 \%$. The sample B \& sample C of soy paneer have average fat percentage values of $1.700 \%$ and $2.55 \%$ respectively as shown in Table 2 . A statistically significant difference was observed in fat percentage of three samples of soymilk and soy paneer. The results obtained were in accordance with the work done by Jain and Mittal [19].

\section{Protein percentage}

The sample A of soymilk consists of $8.0 \%$ proteins on average. The sample B \& sample C of soy paneer have an average protein of $8.7 \%$ and $9.6 \%$ respectively as shown in Table 1 .

The average protein percentage in soy paneer sample A was $7.6 \%$. The sample B \& sample C of soy paneer have average protein percentage values of $8.8 \%$ and $9.6 \%$ respectively as shown in Table 2 . A statistically significant difference was observed in protein content of three samples of soymilk and soy paneer.

\section{Moisture percentage}

The average moisture percentage in soymilk sample A was found to be 88.35 . The sample B \& sample C of soymilk have an average moisture percentage of 82.94 and 80.55 respectively as shown in Table 1 .

The sample A of soy paneer was found to have 88.68 moisture percentages. The sample B \& sample $C$ of soy paneer have moisture percentage values of 85.32 and 82.65 respectively as shown in Table 2. There was a non-significant difference in moisture content in three samples.

\section{Titrable acidity}

The average value of acidity in soymilk sample A was calculated as $0.63 \%$. The sample B \& sample C of soymilk have acidity of $0.65 \%$ and $0.74 \%$ respectively as shown in Table 1 .

The sample A of soy paneer consists of $0.57 \%$ acidity. The sample B \& sample C of soy paneer have acidity values of $0.62 \%$ and $0.70 \%$ respectively as shown in Table 2 . There was a no significant difference in acidity in three samples of soymilk and soy paneer. The ratio of soy milk and skim milk had no significant effect on titrable acidity. It is in accordance with the work done by.

\section{Specific gravity}

The specific gravity of soymilk sample A was found to be 0.98 . The soymilk sample B \& sample C has mean specific gravity values of 1.0 and 1.03 respectively as shown in Table 1 . A significant difference was observed in specific gravity of the three samples.

\begin{tabular}{|l|l|l|l|l|l|l|l|l|}
\hline Sample & $\begin{array}{l}\text { Fat } \\
\%\end{array}$ & $\begin{array}{l}\text { Protein } \\
\%\end{array}$ & $\begin{array}{l}\text { Moisture } \\
\text { content }\end{array}$ & Acidity & $\begin{array}{l}\text { Sp. } \\
\text { Gravity }\end{array}$ & Ash \% & $\begin{array}{l}\text { Lactose } \\
\%\end{array}$ & T.S.S \\
\hline A & 1.85 & 8 & 88.35 & 0.63 & 0.98 & 1.8 & 0 & 7 \\
\hline B & 1.9 & 8.7 & 82.94 & 0.65 & 1.9 & 0.38 & 4.5 & 7.3 \\
\hline C & 2.55 & 9.6 & 80.55 & 0.74 & 2.35 & 0.47 & 5 & 8 \\
\hline \\
Table 1: Chemical composition of soymilk samples. \\
\hline Sample & Fat \% & Protein \% & $\begin{array}{l}\text { Moisture } \\
\%\end{array}$ & $\begin{array}{l}\text { Lactose } \\
\%\end{array}$ & Acidity & Ash \% \\
\hline A & 1.85 & 7.6 & 88.68 & 0 & 0.57 & 1.87 \\
\hline B & 1.7 & 8.8 & 85.32 & 3.8 & 0.62 & 0.38 \\
\hline C & 2.55 & 9.6 & 82.65 & 4.7 & 0.7 & 0.47 \\
\hline Mean $\mathbf{E}$ & $2.04 \pm$ & $8.66 \pm$ & $74.76 \pm$ & $2.55 \pm$ & $0.63 \pm$ & $0.38 \pm$ \\
S.E & 0.40 & 0.59 & 2.11 & 1.44 & 0.04 & 0.07 \\
\hline
\end{tabular}

Table 2: Chemical composition of soy paneer samples. 
Citation: Raja J, Punoo HA, Masoodi FA (2014) Comparative Study of Soy Paneer Prepared from Soymilk, Blends of Soymilk and Skimmed Milk. J Food Process Technol 5: 301. doi:10.4172/2157-7110.1000301

\section{Ash percentage}

The average ash percentage in soymilk sample A was calculated as 1.80. The sample B \& sample C of soymilk have ash percentage of 1.96 and 2.35 respectively as shown in Table 1 .

The sample A of soy paneer has ash content of $1.87 \%$. The soy paneer sample B \& sample $C$ have ash content values of $0.38 \%$ and 0.47 $\%$ respectively as shown in Table 2 . A statistically significant difference was observed in ash content of soymilk and soy paneer samples. Similar findings are reported by Krishna [20].

\section{Lactose percentage}

The average lactose percentage in soymilk sample A was calculated as 0 . The soymilk sample B \& sample $C$ has average lactose of $4.5 \%$ and $5.0 \%$ respectively as shown in Table 1 .

The sample A of soy paneer was found to have Zero lactose percentage. The sample B \& sample $\mathrm{C}$ of soy paneer have lactose content values of $3.80 \%$ and $4.70 \%$ respectively as shown in Table 2 . There was a significant difference in lactose percentage in soymilk and soy paneer samples.

\section{Total soluble solids}

The average value of TSS in soymilk sample A was calculated as 7.0. The sample B \& sample C of soymilk have average TSS value of $7.3 \%$ and $8.0 \%$ respectively as shown in Table 1 . A non-significant difference was observed in TSS in three samples.

The differences between my data and findings of Park [21] can be explained by the factors such as differences in experimental parameters and natural qualitative and quantitative variability in the raw material. The yield and quality of soy paneer is affected by soybean and soy milk characteristics and is not affected by the size of soybeans [22].

\section{Sensory evaluation of soy paneer samples}

Sensory evaluation of the soy paneer prepared from different samples was done by using nine-point hedonic [17]. The various

\begin{tabular}{|c|c|c|c|c|c|}
\hline Samples & Colour & Flavour & Taste & Texture & Overall acceptability \\
\hline A & 7.4 & 7.2 & 7.8 & 6.4 & 7.2 \\
\hline B & 7.4 & 6.8 & 7.7 & 6.8 & 7.1 \\
\hline C & 7.8 & 8 & 8.2 & 6.6 & 7.65 \\
\hline
\end{tabular}

Table 3: Average score for sensory evaluation of soy paneer samples.

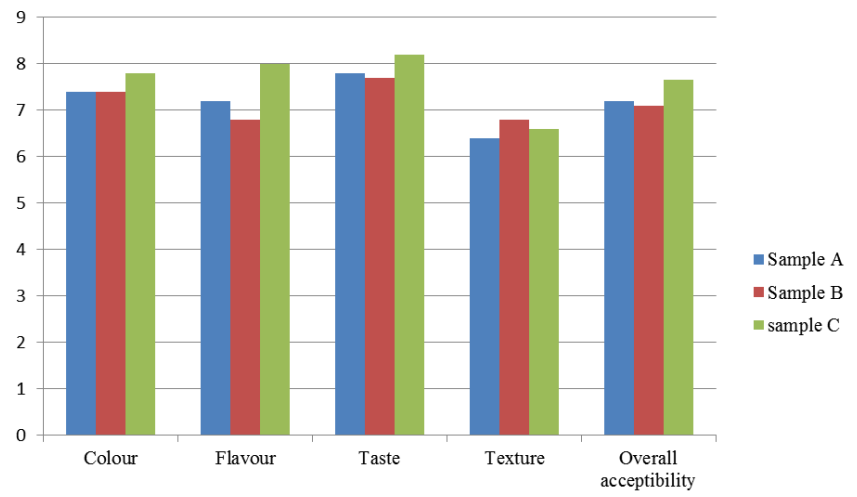

Figure 3: Representation of various sensory parameters of soy paneer in different samples. attributes for which the sample was calculated were colour, flavor, taste, texture and overall acceptability as shown in Table 3 and Figure 3.

The average score for Overall acceptability of the samples A, B and $\mathrm{C}$ was calculated as $7.2,7.1$ and 7.65 respectively. It was found that sample C ( $75 \%$ soymilk and $25 \%$ skimmed by Umunnakwe and Iwuoha [23] on soymilk.

\section{Conclusion}

It was concluded that the sample C with $75 \%$ soymilk and 25 $\%$ skimmed milk was superior in quality with respect to its physical and chemical parameters. The sample C with $75 \%$ soymilk and $25 \%$ skimmed milk can be utilized for the production of soy paneer with higher consumer acceptability. The product can retain its quality attributes especially the colour and flavor during refrigeration storage. This study may help soy paneer manufacturers in India and other countries to control their overall quality. Soy paneer is the richest source of protein for vegetarian people in India. Increasing yield of soy paneer and providing a better texture will make it available for more and more people with increasing preference.

\section{Acknowledgement}

I thank almighty Allah for wisdom, courage and energy bestowed upon me. I also express my heartfelt thanks to the Head of Department Food Science and Technology for providing all the amenities in the form of M.Sc Scholar for carrying out this research. Precious support extended by Dr. Hilal Ahmad Punoo (Assistant Professor), whose encouragement, guidance and support from the initial to the final level enabled me to develop an understanding of the subject.

\section{References}

1. Fan MZ, Sauer WC, de Lange CFM (1995) Amino acid digestibility in soyabean meal, extruded soyabean and full-fat canola for early-weaned pigs. Anim. Feed Sci. Tech. 52: 189-203

2. Poysa V (2002) Stability of soybean seed composition and its effect on soymilk and tofu yield and quality. Food Research International 35: 337-345.

3. Tangratanavale $W$, Pan Z (2003) The characteristics of soybeans as affected by soaking conditions, Lebensmittel-Wissenschaft und-Technologie 36: 143151.

4. Derbyshire E, Wright DJ, Boulter D (1976) Legumin and vicilin storage protein of legume seeds. Phytochemistry, 15: 3-24.

5. Lan CY, Tsai SJ, Kao CS, Chen SC (1981) Studies on the Yield and Quality Characteristics of Tofu. Journal of Food Science 46: 1734-1737.

6. Hou HJ, Chang KC, Shih MC (1997) Yield and textural properties of soft tofu as affected by coagulation method. Journal of Food Science 62: 824-827.

7. Tsai SJ, Lan CY, Kao CS, Chen SC (1981) Studies on the Yield and Quality Characteristics of Tofu. Journal of Food Science 46: 1734-1737.

8. Moizuddin S, Harvey GA, Fenton M, Wilson LA (1999) Tofu production from soybeans or full-fat soy flakes using direct and indirect heating process. Journal of Food Science 64: 145-148.

9. Obatol V (2008) Effect of soybean storage on textural properties. European Food Research Technology, issue May 2008: 467-472.

10. Wilson LA (1995) Soy Foods. Chapter 22 in practical handbook of soybean processing and utilization, AOCS Press. Champaign, IL.

11. Shurtleff,W, Aoyagi A (1979) Tofu and soymilk production, In The book of tofu, volume 2 . New age foods center, Lafayette, CA.

12. Setchell KD (1998) Phytoestrogens the biochemistry, physiology, and implications for human health of soy isoflavones. The American Journal of Clinical Nutrition 68: 1333S 1346S.

13. Sun N, Breene WM (1991) Calcium sulfate concentration influence on yield and quality of tofu from five soybean varieties. Journal of Food Science 56: 1604-1610. 
Citation: Raja J, Punoo HA, Masoodi FA (2014) Comparative Study of Soy Paneer Prepared from Soymilk, Blends of Soymilk and Skimmed Milk. J Food Process Technol 5: 301. doi:10.4172/2157-7110.1000301

Page 5 of 5

14. Wang HL, Swain EW, Kwolek WF (1983) Effect of soybean varieties on the yield and quality of tofu. Cereal Chemistry 60: 245-248.

15. Rangana S (1986) Handbook of analysis and quality control for fruit and vegetable products (second edition). Tata McGraw-Hill publishing company Ltd., Okhala, New Delhi.

16. AOAC (1995) Official Methods of Analysis. (16th edition) Arlington, VA, USA.

17. Watts BM, Ylimaki GL, Jeffery LE, Elias LG (1989) Basic Sensory Methods for Food Evaluation. IDRC, Ottawa.

18. Quinton RD, Cornforth DP, Hendricks DG, Brennand CP, \& Du YK (1997) Acceptability and composition of some acidified meat and vegetable stick products. Journal of Food Science 62: 1250-1254.
19. Jain A, Mittal BK (1992) Characteristics of paneer prepared from different varieties of soybean. Journal of Food Science and Technology 29: 298-300.

20. Krishna A (2003) Physico-chemical characteristics of some new varieties of soybean. Journal of Food Science and Technology 40: 490-492.

21. Park DJ(2005) Characteristics of yogurt-like products prepared from the combination of skim milk and soymilk. Food Chemistry 56: 23-34.

22. Lim BT, DeMan L, Buzzell RI, DeMan JM (1990) Yield and quality of tofu as affected by soybean and soymilk characteristics, Journal of Food Science 55 1088-1092.

23. Iwuoha Cl, Umunnakwe KE (1996) Chemical, physical and sensory characteristics of soymilk as affected by processing method, temperature and duration of storage. Food Chemistry 59: 373-379. 